\title{
HEDONISME KONSUMEN SEBAGAI VARIABEL MEDIATOR ANTARA PEMASARAN DAN PEMBELIAN TIDAK TERENCANA
}

\author{
Stevanus Bayu Satriawan $\left.{ }^{1 *}\right)$, Hartoyo ${ }^{2}$, Lilik Noor Yuliati ${ }^{2}$ \\ ${ }^{1}$ PT. Septia Anugerah, Jakarta Timur 13890, Indonesia \\ ${ }^{2}$ Departemen IImu Keluarga dan Konsumen, Fakultas Ekologi Manusia, Institut Pertanian Bogor, \\ Bogor 16680, Indonesia \\ *) E-mail: bayu_kaka22@yahoo.com
}

\begin{abstract}
Abstrak
Dalam sebuah proses pembelian, konsumen dapat melakukan pembelian secara terencana dan tidak terencana. Pembelian tidak terencana atau seringkali dikenal sebagai pembelian impulsif merupakan respon dari penawaran produk yang relatif tidak mahal seperti produk bakery. Faktor produk, pemasaran, dan karakteristik konsumen ditengarai sebagai faktor yang memengaruhi seseorang melakukan pembelian tidak terencana. Penelitian ini bertujuan untuk menganalisis pengaruh faktor pemasaran dan hedonisme konsumen terhadap keputusan pembelian tidak terencana pada Gerai Roti ABC yang terletak di salah satu pusat perbelanjaan di Kota Bekasi. Pengambilan contoh penelitian menggunakan nonprobability sampling dan jumlah contoh yang terlibat adalah 192 orang konsumen Gerai Roti ABC. Analisis data dilakukan dengan menggunakan Structural Equation Modelling (SEM). Hasil analisis menunjukkan bahwa pada faktor pemasaran, indikator produk dan pemasaran merupakan indikator yang secara signifikan mampu menjelaskan variabel laten faktor pemasaran. Lebih lanjut, faktor pemasaran berpengaruh secara langsung dan signifikan positif terhadap hedonisme konsumen dan juga pemebelian tidak terencana. Faktor pemasaran juga berpengaruh secara tidak langsung dan signifikan positif terhadap pembelian tidak terencana melalui hedonisme konsumen di Gerai Roti ABC.
\end{abstract}

Kata kunci: Gerai Roti, hedonisme konsumen, pemasaran, produk, SEM

\section{Consumer Hedonism as Mediator Variable of Marketing Factors and Unplanned Purchase Behavior}

\begin{abstract}
In a process of purchase, consumers can conduct planned purchase or unplanned purchase behavior. Unplanned purchase behavior, also known as impulsive purcahse behavior, refers to consumers' response to marketing of product that is not extremely expensive including bakery product. Product and marketing factors, and also consumers' characteristics are identified as determinant factors of unplanned purchase behavior. This research aimed to examine influence of marketing factors and consumer hedonism on unplanned purchase behavior of consumers of bakey outlet that was located in one of shopping center in the city of Bekasi. The sampling in this research used non-probability sampling. The number of the respondents was 192 people that became consumers of ABC bakery outlet. The analysis data used Structural Equation Modelling (SEM). The result showed that product and marketing indicator were significant indicators of latent variable of marketing factors (marketing mix). Moreovver, marketing factors had direct influence on consumer hedonism and unplanned purchase behavior positive significantly. Marketing factors also influenced indirectly on unplanned purchase behavior positive significantly; with consumer hedonism as mediator variable.
\end{abstract}

Keywords: bakery outlet, consumer hedonism, marketing factors, product, SEM

\section{PENDAHULUAN}

Dalam sebuah proses pembelian, konsumen dapat melakukan pembelian secara terencana (planned purchase) dan tidak terencana (unplanned purchase). Pembelian terencana adalah aktivitas yang terjadi karena ada masalah dan sudah muncul niat untuk membeli sebelum pembelian terjadi. Sementara itu, pembelian tidak terencana adalah aktivitas pembelian yang terjadi karena adanya dorongan untuk membeli yang disebabkan karena melihat pajangan, iklan, percobaan barang baru atau kedatangan tenaga penjual. Solomon (2011) mengatakan dorongan untuk membeli tanpa terencana (impulse buying) terjadi ketika seseorang mengalami perasaan ingin membeli secara tiba-tiba, mendesak dan tidak bisa menahan dalam kurun waktu seketika. Proses otomatisasi perilaku impulse buying yang terjadi disebabkan adanya stimulasi kuat dari lingkungan yang muncul 
sedemikian rupa tanpa dilandasi oleh pertimbangan kebutuhan secara rasional. Hausman (2000) menyatakan bahwa pembelian impulsif merupakan respon dari penawaran produk yang relatif tidak mahal. Penjual sangat sadar bahwa bagian volume penjualan yang cukup besar seringkali dibangkitkan oleh sifat pembelian impulsif. Hal ini ditunjukkan dari fakta bahwa sepertiga pembelian pada department store dilakukan secara impulsif (Bellenger et al., 1978, diacu dalam Hetharie, 2012). Hasil kajian Park (2006), diacu dalam Hetharie (2012) menyatakan bahwa diperkirakan lebih dari 4 miliar US\$ penjualan tahunan di Amerika Serikat terjadi melalui pembelian impulsif.

Loudon dan Bitta dalam Widawati (2011) menemukan beberapa faktor yang dapat memengaruhi pembelian tidak terencana yaitu: (1) karakteristik produk secara umum meliputi harga yang murah, adanya sedikit kebutuhan terhadap produk tersebut, siklus kehidupan produknya pendek, ukurannya kecil atau ringan, dan mudah disimpan, (2) faktor pemasaran yang meliputi ketersediaan informasi mulai dari iklan hingga material yang akan didiskon, posisi pajangan produk dan lokasi toko serta jumlah, lokasi dan jarak toko, (3) karakteristik konsumen yang mencakup kepribadian konsumen termasuk di dalamnya nilai hedonimisme konsumen, gaya hidup, dan karakteristik demografi seperti jenis kelamin, usia status perkawinan, penghasilan, pekerjaan dan pendidikan.

Besarnya pengaruh faktor pemasaran terlihat dalam kajian terdahulu (Bong, 2011) yang menemukan adanya pengaruh signifikan langsung dari upaya stimulus oleh manajemen toko terhadap perilaku pembelian tidak terencana. Hasil penelitian tersebut memperkuat teori bahwa in-store stimuli (faktor pemasaran) berpengaruh positif terhadap pembelian pembelian tidak terencana. Selain itu, Yistiani (2012) juga menemukan bahwa atmosfer gerai, pelayanan ritel, dan nilai hedonisme berpengaruh positif dan signifikan terhadap pembelian tidak terencana. Temuan tersebut menunjukkan pengaruh faktor pemasaran yang diwakili variabel atmosfer gerai dan pelayanan ritel serta faktor karakteristik konsumen yang diwakili variabel nilai hedonisme sebagai faktor yang berpengaruh terhadap pembelian tidak terencana. Oleh karenanya, penelitian pada Gerai Roti (bakery) yang merupakan produk dengan harga yang tidak mahal perlu dilakukan untuk menjelaskan pengaruh faktor pemasaran dan nilai hedonisme konsumen terhadap pembelian tidak terencana.

Pada suatu perusahaan, pemasaran merupakan salah satu kunci penting berhasilnya suatu jenis usaha. Kotler dan Keller (2009) menjelaskan inti dari pemasaran adalah mengidentifikasi dan memenuhi kebutuhan manusia dan sosial. Swastha (2006) menyebutkan ada empat faktor utama dalam pemasaran yang dikenal dengan marketing mix yang terdiri atas produk, harga, promosi, dan lokasi. Sementara itu, nilai hedonisme konsumen melekat pada kegiatan berbelanja sebagai kegiatan yang menyenangkan (Musriha 2011). Hedonic shopping menurut Japarianto (2011) merupakan suatu keinginan seseorang untuk mendapatkan suatu kesenangan bagi dirinya sendiri yang dapat dipenuhi dengan cara menghabiskan waktu untuk mengunjungi pusat perbelanjaan atau mall, menikmati suasana atau atmosfer yang ada di pusat perbelanjaan itu sendiri meskipun mereka tidak membeli apapun atau hanya melihat-lihat saja. Nilai hedonisme dipercaya dapat berpotensi memberikan hiburan dalam berbelanja. Berdasarkan pengertian-pengertian tersebut dapat dielaborasi bahwa hedonisme konsumen lebih terkait dengan sisi emosional konsumen daripada sisi rasionalnya. Pengertian nilai hedonisme konsumen tersebut yang mengarahkan pada dugaan bahwa selain faktor pemasaran, nilai hedonisme juga berpengaruh terhadap pembelian tidak terencana pada Gerai Roti self-service yang berlokasi di pusat perbelanjaan.

Gerai Roti berusaha menyampaikan stimulus kepada konsumen untuk meningkatkan pembelian. Stimulus yang biasa dilakukan para pemasar antara lain iklan, potongan harga, aroma, dan kesempatan mencicipi. Gerai Roti ABC waralaba yang berlokasi di salah satu pusat perbelanjaan besar di Kota Bekasi menggunakan metode komunikasi pemasaran secara nonverbal, yaitu secara tidak langsung menginformasikan rasa yang ditawarkan melalui aroma roti yang dibuat. Susilowati (2012) menyebutkan bahwa komunikasi pemasaran adalah aktivitas pemasaran yang berusaha menciptakan kesadaran atau pengetahuan mengenai produk dengan berbagai atributnya, menginformasikan kelebihan produk, menciptakan citra produk atau menciptakan preferensi, dan keinginan membeli produk bersangkutan. Gerai Roti ABC ini juga membuat suatu konsep promosi melalui open kitchen yang mana dapur pengolahan roti dibuat menjadi satu dengan area penjualan 
serta dibuat agar terlihat terbuka sehingga konsumen bisa melihat dan mengambil sendiri roti yang akan dibelinya (self-service). Kondisi Gerai Roti ABC tersebut dapat secara spontan membuat pembelian yang tidak direncakan sebelumnya. Berdasarkan rumusan latar belakang dan kondisi Gerai Roti ABC tersebut maka tujuan dalam penelitian ini adalah menganalisis pengaruh faktor pemasaran dan hedonisme konsumen terhadap keputusan pembelian tidak terencana.

\section{METODE}

Desain penelitian ini adalah cross sectional dan dilakukan di Gerai Roti ABC waralaba yang berlokasi di salah satu pusat perbelanjaan besar di Kota Bekasi. Populasi dalam penelitian ini adalah konsumen Gerai Roti $A B C$ yang membeli secara tidak terencana. Populasi dalam penelitian ini tidak terbatas (infinite), karena jumlah yang tidak diketahui dan identitas konsumen yang sulit untuk di identifikasi. Contoh dalam penelitian ini adalah pembeli Gerai Roti ABC yang membeli secara tidak terencana. Pengambilan contoh dalam penelitian ini menggunakan nonprobability sampling. Teknik nonprobability sampling yang digunakan adalah teknik convinience sampling. Teknik sampling ini adalah pengambilan contoh tanpa mempertimbangkan siapa yang akan dijadikan subjek atau responden penelitiannya, serta bagaimana cara memilih anggota contoh. Teknik sampling ini dipilih karena populasi konsumen dan profil konsumen yang tidak diketahui secara pasti dan peneliti beranggapan bahwa konsumen merupakan sumber informasi terbaik untuk memperoleh data penelitian ini. Pengambilan contoh dibagi menjadi 7 hari dimulai hari Senin berakhir hari minggu. Setiap harinya dibagi 3 waktu pengambilan, yaitu: siang pukul 11.00-13.00, sore pukul 15.0017.00, malam pukul 19.00-21.00. Setiap waktu tersebut ditargetkan mendapatkan minimal 9 responden dan maksimal 11 responden. Jumlah contoh dalam penelitian ini sebanyak 192 pembeli yang sekaligus menjadi responden.

Pengumpulan data primer diperoleh melalui pengisian kuesioner oleh responden. Data karakteristik responden meliputi usia, jenis kelamin, pendidikan, pekerjaan, dan pendapatan. Usia dikelompokan berdasarkan katagori yang berusia $<18$ tahun, 18-23 tahun, 24-29 tahun, 30-35 tahun dan $>35$ tahun. Jenis kelamin dikelompokan menjadi laki-laki dan perempuan. Pendidikan dikelompokan berdasarkan tingkat pendidikan, yaitu: (1) SD,
(2) SMP, (3) SMA, (4) D3/S1, (5) S2, (6) S3. Pekerjaan dikelompokan menjadi (1) PNS, (2) pegawai swasta,(3) pelajar/mahasiswa, (4) ibu rumah tangga, (5) lainnya dengan menyebutkan jenis pekerjaan yang belum terdapat dalam kuesioner. Pendapatan dikelompokan menjadi (1) $\leq \mathrm{Rp} 1.000 .000$, (2) Rp1.001.000-Rp2.000.000, (3) Rp2.001.000Rp3.000.000, (4) Rp3.001.000-Rp4.000.000, dan (5) >Rp4.000.000.

Faktor pemasaran dalam penelitian ini diukur dengan lima subvariabel, yaitu produk (empat pernyataan), harga (dua pernyataan), promosi (empat pernyataan), lokasi (satu pernyataan), self-service (satu pernyataan). Sementara itu, nilai hedonisme konsumen diukur dengan tiga indikator yaitu bahwa membeli di Gerai Roti self-service merupakan kegiatan yang membahagiakan, menyenangkan, dan menjadi hiburan. Pembelian tidak terencana dalam penelitian ini diukur dengan empat indikator, yaitu: (1) spontanitas, (2) kegairahan dan stimulasi, (3) kekuatan, kompulsi, dan intensitas, dan (4) ketidakpedulian akibat. Ketiga variabel tersebut diukur dengan menggunakan skala jawaban Likert dari 1 hingga 5. Penelitian ini menggunakan analisis Structural Equation Modelling (SEM) untuk menjelaskan pengaruh variabel pemasaran dan nilai hedonisme konsumen terhadap pembelian tidak terencana. Instrumen yang digunakan dalam penelitian ini telah reliabel dan valid yang ditunjukkan dari nilai Cronbach's alpha 0,779 untuk faktor pemasaran, 0,782 untuk instrumen nilai hedonisme konsumen, dan 0,784 untuk instrumen pembelian impulsif.

\section{HASIL}

\section{Kondisi Sosial Demografi}

Berdasarkan hasil penelitian, data demografi konsumen dilihat dari jenis kelamin didominasi oleh wanita sebanyak 77 persen, sedangkan lelaki hanya sebanyak 23 persen. Penelitian ini menunjukkan bahwa umur sebagian besar konsumen berumur 24-29 tahun yaitu sebesar 40 persen, konsumen berumur 19-23 tahun sebanyak 26 persen, 17 persen konsumen berumur 30-35 tahun, 8 persen konsumen berumur $>35$ tahun, dan sebanyak 4 persen berumur $<18$ tahun. Berdasarkan pendidikan konsumen, kebanyakan konsumen berpendidikan D3/S1 dengan jumlah 69 persen, konsumen yang berpendidikan SMA sebanyak 26 persen, konsumen berpendidikan SMP 3 persen, dan 
konsumen berpendidikan S2 berjumlah 1 persen. Hasil penelitian juga menunjukkan bahwa tidak ada konsumen yang memiiki pendidikan terakhir SD dan S3. Pekerjaan konsumen didominasi oleh pegawai swasta dengan jumlah 61 persen, pelajar/mahasiswa berjumlah 38 persen, ibu rumah tangga berjumlah 14 persen, PNS (Sipil, Polri, TNI) berjumlah 3 persen. Pegawai swasta merupakan mayoritas pembeli tidak terencana di Gerai Roti ABC. Hal Ini dikarenakan di kota Bekasi banyak beroperasi kantor-kantor swasta dan bank-bank swasta. Pendapatan contoh terbesar pada angka Rp2.001.000-3.000.000 dengan jumlah 32 persen. Untuk pendapatan Rp3.001.000-4.000.000 terdapat 29 persen, pendapatan $>\mathrm{Rp} 4.000 .000$ terdapat 16 persen, pendapatan Rp1.001.000-2.000.000 terdapat 14 persen, dan pendapatan <Rp1.000.000 terdapat 6 persen.

\section{Faktor Pemasaran}

Dalam penelitian ini, faktor pemasaran merupakan variabel bebas yang diduga berpengaruh terhadap pembelian tidak terencana konsumen pada Gerai Roti ABC. Hasil penelitian menunjukkan bahwa seluruh indikator yang dipakai untuk menilai faktor pemasaran sudah dinilai/dipersepsikan positif oleh konsumen, kecuali untuk lokasi yang mudah dijangkau dari tempat parkir (X9), membeli roti $A B C$ karena merek luar negeri (X11), dan membeli roti ABC karena mereknya sudah terkenal (X12). Jawaban konsumen sebagian besar untuk sembilan indikator faktor pemasaran berada dalam rentang setuju dan sangat setuju. Sementara itu, untuk indikator lokasi yang mudah dijangkau dari tempat parkir (X9), membeli roti $A B C$ karena merek luar negeri (X11), dan membeli roti $A B C$ karena mereknya sudah terkenal (X12) jawaban terbayak konsumen adalah pada rentang kurang setuju.

Indikator faktor pemasaran yang paling banyak mendapat jawaban sangat setuju (SS) adalah bahwa roti $\mathrm{ABC}$ mempunyai varian roti yang beraneka ragam (X1) sebesar 46,88 persen. Sementara itu, indikator bahwa roti ABC menjanjikan kualitas roti yang baik (X6) paling banyak mendapat jawaban setuju (S) dari konsumen yaitu sebesar 73,44 persen. Pada indikator faktor pemasaran yang kurang mendapatkan respon positif, indikator membeli roti $A B C$ karena merek luar negeri (X11) mendapat jawaban kurang setuju (KS) tertinggi yaitu sebesar 48,96 persen. Indikator tersebut juga mendapat jawaban tidak setuju (TS) tertinggi yaitu 28,65 persen dan jawaban tertinggi untuk sangat tidak setuju tertinggi (STS) yaitu 5,73 persen. Sementara pada indikator lokasi yang mudah dijangkau dari tempat parkir (X9) dan membeli roti $A B C$ karena mereknya sudah terkenal (X12) mempunyai proporsi terbesar pada jawaban kurang setuju masing-masing 46,88 persen dan 45,31 persen.

\section{Nilai Hedonisme Konsumen}

Fathonah (2009) menyebutkan bahwa nilai hedonisme dipercaya dapat berpotensi memberikan hiburan dalam berbelanja. Rachmawati (2009) menemukan bahwa nilai hedonisme yang dimiliki konsumen memengaruhi secara signifikan pembelian tidak terencana (perilaku pembelian impulsif). Hasil penelitian menunjukkan bahwa dari kelima indikator nilai hedonisme kosumen ( $Y 1$ hingga $Y 5$ ), menikmati kegiatan membeli roti $A B C(Y 1)$ dan merasa senang saat membeli roti $A B C$ (Y2) paling dipersepsikan positif oleh konsumen dengan jawaban terbanyak pada setuju. Sementara itu, untuk indikator tiga yang lain, jawaban terbanyak adalah jawaban kurang setuju. Indikator nilai hedonisme paling banyak mendapat jawaban sangat setuju (SS) adalah menikmati kegiatan membeli roti $A B C$ ( $Y 1)$ dengan 7,81 persen konsumen. Indikator yang mendapat paling banyak mendapat jawaban setuju pada variabel nilai hedonisme adalah merasa senang saat membeli roti $A B C$ (Y2) dengan 69,79 persen konsumen. Hasil lain juga menunjukkan bahwa indikator yang mendapat paling banyak jawaban kurang setuju adalah merasa bangga saat belanja ABC (Y5) dengan 46,35 persen konsumen. Indikator nilai hedonisme yang mendapat paling banyak jawaban tidak setuju adalah kegiatan membeli roti $A B C$ merupakan hiburan bagi konsumen (Y3) dengan 16,67 persen. Sementara itu, indikator yang mendapat paling banyak mendapat jawaban sangat tidak setuju adalah konsumen merasa bangga saat belanja roti $A B C$ (Y5) dengan 3,13 persen.

\section{Pembelian Tidak Terencana (Perilaku Pembelian Impulsif)}

Solomon (2011) mengatakan pembelian tidak terencana (impulse buying) terjadi ketika seseorang mengalami perasaan ingin membeli secara tiba-tiba, mendesak dan tidak bisa menahan. Pengukuran pembelian tidak terencana dalam penelitian ini menggunakan sembilan indikator. Selanjutnya tingkat impulsif yang menggambarkan tingkatan pembelian 
tidak terencana konsumen akan dibagi menjadi tiga kelompok, yaitu rendah, sedang dan tinggi. Pembagian kelompoknya didasarkan pada total jumlah jawaban minimal dari 9 indikator yaitu 9 dan total jawaban maksimal yaitu 45. Rentang dari skor jawaban minimal dan maksimal adalah 36 (45-9). Berdasarkan skor yang diperoleh maka tingkat impulsif rendah adalah pada rentang skor 9-20, sedang pada rentang skor 21-32, dan tinggi pada rentang skor 33-45.

Hasil penelitian ini menunjukkan bahwa indikator sering membeli sesuatu secara spontan atau tidak terencana (Y6) dan saat berada di Gerai Roti ABC konsumen memilih jenis roti yang konsumen beli, sesuai selera konsumen saat itu (Y13) paling dipersepsikan positif oleh konsumen dengan jawaban terbanyak pada setuju (S). Dari kesembilan indikator pada perilaku pembelian tidak terencana (Y6 hingga $Y 14$ ), indikator yang paling banyak mendapat jawaban sangat setuju dan setuju adalah saat berada di Gerai Roti ABC konsumen memilih jenis roti yang konsumen beli, sesuai selera konsumen saat itu (Y13) dengan 26,56 dan 69,79 persen konsumen. Sementara itu, indikator yang mendapat paling banyak mendapat jawaban kurang setuju adalah konsumen membeli roti ABC tanpa berpikir dahulu tentang jumlah yang dibutuhkan (Y12) dengan 51,56 peersen konsumen. Hasil lain juga menunjukkan bahwa indikator yang mendapat paling banyak mendapat jawaban tidak setuju dan sangat tidak setuju adalah konsumen berhati-hati saat merencanakan pembelian roti $A B C$ (Y14) dengan 47,40 persen dan 5,73 persen konsumen.

Untuk dapat memberikan gambaran yang lebih rinci perilaku pembelian tidak terencana konsumen pada Gerai Roti $A B C$, analisis juga dilakukan berdasarkan jenis kelamin, usia, pendidikan, pekerjaan, dan pendapatan konsumen. Hasil penelitian menunjukkan bahwa proporsi konsumen lelaki berperilaku impulsif rendah sebesar 15,2 persen berperilaku impulsif sedang 71,7 persen, dan berperilaku impulsif tinggi sebesar 13 persen. Sementara itu, pada konsumen perempuan berperilaku impulsif rendah sebesar 0,7 persen, berperilaku impulsif sedang 71,9 persen, dan berperilaku impulsif tinggi 27,4 persen. Hasil penelitian tersebut menunjukkan bahwa konsumen perempuan yang berperilaku impulsif tinggi dalam membeli roti di Gerai Roti ABC lebih besar proporsinya dibandingkan konsumen laki-laki. Hal ini dapat terjadi karena konsumen lelaki lebih menggunakan rasional dibanding dengan emosional.
Sementara itu, hasil penelitian lain juga menunjukkan bahwa konsumen usia di bawah 18 tahun mempunyai perilaku impulsif rendah sebesar 0 persen, berperilaku impulsif sedang 87,5 persen, dan berperilaku impulsif tinggi sebesar 12,5 persen. Sementara itu, pada konsumen dengan usia 18-23 tahun menunjukkan bahwa konsumen yang memiliki impulsif rendah sebesar 1,9 persen, berperilaku impulsif sedang 79,2 persen, dan berperilaku impulsif tinggi sebesar 18,9 persen. Pada konsumen usia 24-29 tahun, perilaku impulsif rendah menunjukkan hasil sebesar 2,5 persen, berperilaku impulsif sedang sebesar 69,1 persen, dan berperilaku impulsif tinggi sebesar 28,4 persen. Konsumen usia 30-35 tahun yang menunjukkan perilaku impulsif rendah sebesar 12,1 persen, berperilaku impulsif sedang sebesar 63,6 persen, dan berperilaku impulsif tinggi sebesar 24,2 persen. Sementara itu, pada kelompok usia di atas 35 tahun hasil penelitian menunjukkan bahwa perilaku impulsif rendah mempunyai proporsi sebesar 5,9 persen, yang berperilaku impulsif sedang sebesar 70,6 persen, dan yang berperilaku impulsif tinggi sebesar 23,5 persen. Hasil penelitian menunjukkan bahwa pada semua kelompok umur, proporsi terbesar adalah pada perilaku impulsif sedang. Perilaku impulsif tinggi yang tertinggi berada pada responden dengan usia 24-29 Tahun. Hal ini dimungkinkan karena pada tingkat umur tersebut adalah tingkat umur yang mana responden sudah memiliki kemampunan untuk memutuskan dan sudah memiliki penghasilan sendiri. Selain itu, pada tingkat usia tersebut merupakan tingkat usia yang matang namun masih mudah untuk dipengaruhi dengan pemasaran yang tepat. Pada usia 18-23 tahun juga berperilaku impulsif namun jumlahnya masih relatif sedikit, dimungkinkan karena lebih mudah untuk dipengaruhi namun belum memiliki daya beli yang kuat.

Sementara itu, berdasarkan tingkat pendidikan konsumen, hasil penelitian menunjukkan bahwa semua konsumen pada kelompok pendidikan SMP berperilaku impulsif sedang dan tidak ada satupun konsumen pada level pendidikan ini yang berperilaku impulsif rendah dan tinggi. Pada tingkat pendidikan SMA yang berperilaku impulsif rendah sebesar 4,1 persen, berperilaku impulsif sedang sebesar 75,5 persen, dan yang berperilaku impulsif tinggi sebesar 20,4 persen. Sementara itu, pada tingkat pendidikan D3/S1 yang berperilaku impulsif rendah sebesar 4,5 persen, sedangkan yang berperilaku impulsif sedang sebesar 69,4 persen, dan berperilaku impulsif 
tinggi sebesar 26,1 persen. Pada tingkat pendidikan S2 tidak ada konsumen yang mempunyai perilaku impulsif rendah dan pada kelompok sedang dan tinggi proporsinya sama yaitu masing-masing 50 persen. Hasil penelitian ini menunjukkan bahwa pada semua tingkat pendidikan, mayoritas konsumen mempunyai perilaku impulsif sedang. Namun pada tingkat pendidikan SMA dan D3/S1 cenderung lebih berperilaku impulsif, dimungkinkan karena pada tingkat pendidikan tersebut memiliki pergaulan yang lebih luas, banyak menyerap informasi dan promosi yang dilakukan, dan sudah mulai memiliki pendapatan atau memegang uang sendiri sehingga lebih mudah untuk melakukan keputusan pembelian.

Penelitian ini juga menganalisis tingkat impulsif konsumen pada Gerai Roti berdasarkan pekerjaannya. Hasil pada penelitian ini menunjukkan bahwa tidak ada konsumen dengan pekerjaan PNS yang mempunyai perilaku impulsif rendah dan untuk yang mempunyai perilaku impulsif sedang adalah sebesar 83,3 persen dan tinggi sebesar 16,7 persen. Sementara itu, untuk karyawan yang berstatus sebagai pegawai swasta, berperilaku impulsif rendah sebesar 5,0 persen, berperilaku impulsif sedang 70,6 persen, dan berperilaku impulsif tinggi sebesar 24,4 persen. Pelajar/ mahasiswa menunjukkan yang berperilaku impulsif rendah sebesar 2,6 persen, berperilaku impulsif sedang sebesar 76,9 persen, dan berperilaku impulsif tinggi sebesar 20,5 persen. Hasil pada kelompok ibu rumah tangga adalah tidak ada yang berperilaku impulsif rendah namun untuk perilaku impulsif sedang adalah sebesar 70,4 persen, dan berperilaku impulsif tinggi sebesar 29,6 persen. Hasil penelitian ini juga menunjukkan bahwa semua konsumen yang tidak berprofesi sebagai PNS, pegawai swasta, pelajar/mahasiswa, dan ibu rumah tangga, mempunyai perilaku impulsif pada kategori rendah. Hasil penelitian yang menunjukkan bahwa pada profesi PNS dan pegawai swasta mempunyai tingkat pembelian impulsif lebih tinggi dapat terjadi terjadi karena adanya faktor pendapatan yang rutin sehingga lebih leluasa dalam membuat keputusan pembelian.

Sementara itu, apabila tingkat pembelian impulsif dilihat berdasarkan kelompok pendapatan konsumen, hasil penelitian menunjukkan bahwa konsumen dengan pendapatan kurang dari $\mathrm{Rp} 1.000 .000$ berperilaku impulsif sedang sebesar 75 persen, berperilaku impulsif tinggi sebesar 25 persen dan tidak ada yang mempunyai perilaku impulsif rendah.
Selanjutnya, konsumen dengan pendapatan Rp 1.001 .000 hingga $\mathrm{Rp} 2.000 .000$ yang berperilaku impulsif rendah sebesar 7,1 persen, berperilaku impulsif sedang 78,6 persen, dan berperilaku impulsif tinggi sebesar 14,3 persen. Konsumen dengan pendapatan $\mathrm{Rp} 2.001 .000$ sampai dengan Rp 3.000.000 yang berperilaku impulsif rendah sebesar 6,6 persen, berperilaku impulsif sedang sebesar 67,2 persen, dan berperilaku impulsif tinggi sebesar 26,2 persen. Pada kelompok konsumen dengan pendapatan Rp 3.001.000 hingga Rp 4.000.000 berperilaku impulsif sedang sebesar 1,7 persen, berperilaku impulsif sedang sebesar 63,8 persen, dan berperilaku impulsif tinggi sebesar 34,5 persen. Sementara itu, pada konsumen dengan pendapatan di atas Rp 4.000 .000 yang berperilaku impulsif rendah sebesar 3,0 persen, yang berperilaku impulsif sedang sebesar 87,9 persen, dan yang berperilaku impulsif tinggi sebesar 9,1 persen. Hasil tersebut menunjukkan bahwa konsep pemasaran dan produk yang tepat akan dapat menarik pemilik pendapatan sedang yaitu Rp. 2.001.0003.000.000 dan Rp 3.001.000-4.000.000 untuk lebih berperilaku impulsif.

Selanjutnya, untuk mengidentifikasi faktorfaktor yang berpengaruh terhadap pembelian impulsif penelitian ini menggunakan SEM (Structural Equation Modeling). Langkah awal dalam analisis SEM yaitu melakukan evaluasi pengujian asumsi kelayakan model (goodness of fit model). Asumsi ini dilakukan untuk mengetahui apakah model dapat digunakan serta dapat dipercaya atau tidak. Ada beberapa kriteria yang perlu diuji, diantaranya menggunakan pendekatan NFI (Normed Fit Index ), CFI (Comparative Fit Index), RMSEA (Root Mean square Error of Approximation), dan GFI (Goodness of Fit). Hasil dari pengukuran goodness of fit index tersebut dapat dilihat pada Tabel 1.

Tabel 1 Hasil goodness of fit model

\begin{tabular}{llll}
\hline $\begin{array}{l}\text { Goodness-of- } \\
\text { Fit }\end{array}$ & $\begin{array}{c}\text { Cutt-off- } \\
\text { Value }\end{array}$ & Hasil & Keterangan \\
\hline $\begin{array}{l}\text { RMSEA(Root } \\
\begin{array}{l}\text { Mean square } \\
\text { Error of }\end{array}\end{array}$ & $\leq 0,08$ & 0.051 & Good Fit \\
$\begin{array}{l}\text { Approximation) } \\
\text { GFI(Goodness } \\
\text { of Fit) }\end{array}$ & $\geq 0,90$ & 0.92 & Good Fit \\
$\begin{array}{l}\text { CFI } \\
\text { (Comparative }\end{array}$ & $\geq 0,90$ & 0.96 & Good Fit \\
Fit Index) & & & \\
$\begin{array}{l}\text { NFI (Normed } \\
\text { Fit Index) }\end{array}$ & $\geq 0,95$ & 0.9 & Marjinal Fit \\
\hline
\end{tabular}


Setelah melihat hasil pengujian kelayakan model, selanjutnya dapat dilihat mengenai pengaruh atau hubungan antarvariabel laten atau model struktural dan hubungan antara variabel laten terhadap indikatornya atau model pengukuran. Selain itu, masing-masing hubungan ditunjukkan hasil pengujian hipotesis uji $T$ (uji signifikansi pengaruh/hubungan), dimana setiap pengaruh/hubungan yang memiliki nilai uji $T$ lebih besar 1,96 menghasilkan kesimpulan signifikan dan begitu sebaliknya. Hasil estimasi faktor muatan (loading factor) seperti yang tersaji pada Gambar 1 menunjukkan bahwa semua variabel laten (faktor pemasaran dan nilai hedonisme kosumen) berpengaruh signifikan terhadap pembelian impulsif. Koefisien regresi terbesar adalah faktor pemasaran sebesar 0,39, sedangkan untuk nilai hedonisme konsumen mempunyai koefisien sebesar 0,36. Variabel laten untuk pembelian impulsif semua berpengaruh signifikan dengan $\mathrm{T}$ hitung lebih dari 1,96 dan yang mempunyai nilai terbesar adalah faktor pemasaran dengan nilai T Hitung sebesar 6,22 (Gambar 2). Faktor pemasaran sebagai variabel laten untuk nilai hedonisme mempunyai $T$ Hitung 3,58 (>1,96), sehingga semua variabel laten faktor pemasaran ini berpengaruh signifikan terhadap hedonik. Koefisien regresi faktor pemasaran terhadap nilai hedonisme sebesar 0,63.
Faktor pemasaran dalam penelitian ini memiliki empat indikator, yaitu product, price, place dan promotion. Setelah melakukan pengolahan data, keempat indikator tersebut terbukti signifkan dan berpengaruh positif. Berdasarkan hasil analisis faktor muatan maka indikator promotion adalah faktor tertinggi yang berpengaruh terhadap faktor pemasaran sebesar 0,85. Faktor yang paling berpengaruh kedua adalah product sebesar 0,61, kemudian place sebesar 0,44 , dan yang terakhir adalah price 0,42 . Hasil penelitian ini menunjukkan bahwa sistem pemasaran yang digunakan oleh Gerai Roti ABC terbukti mampu untuk menarik perhatian konsumen. Sistem open kitchen misalnya merupakan salah satu strategi pemasaran yang mampu membuat konsumen tertarik untuk melakukan pembelian. Penyajian produk yang berbeda dengan yang lain juga menjadi daya tarik bagi konsumen untuk memengaruhi nilai hedoonisme konsumen yang selanjutnya juga akan memengaruhi perilaku pembelian tidak terencana. Konsep self-service juga membuat konsumen merasa lebih yakin dengan kualitas produk maupun rasa dan nyaman saat membeli. Dari keempat indikator, price menjadi faktor yang terendah namun harga yang ditawarkan tetap dapat dijangkau konsumen.

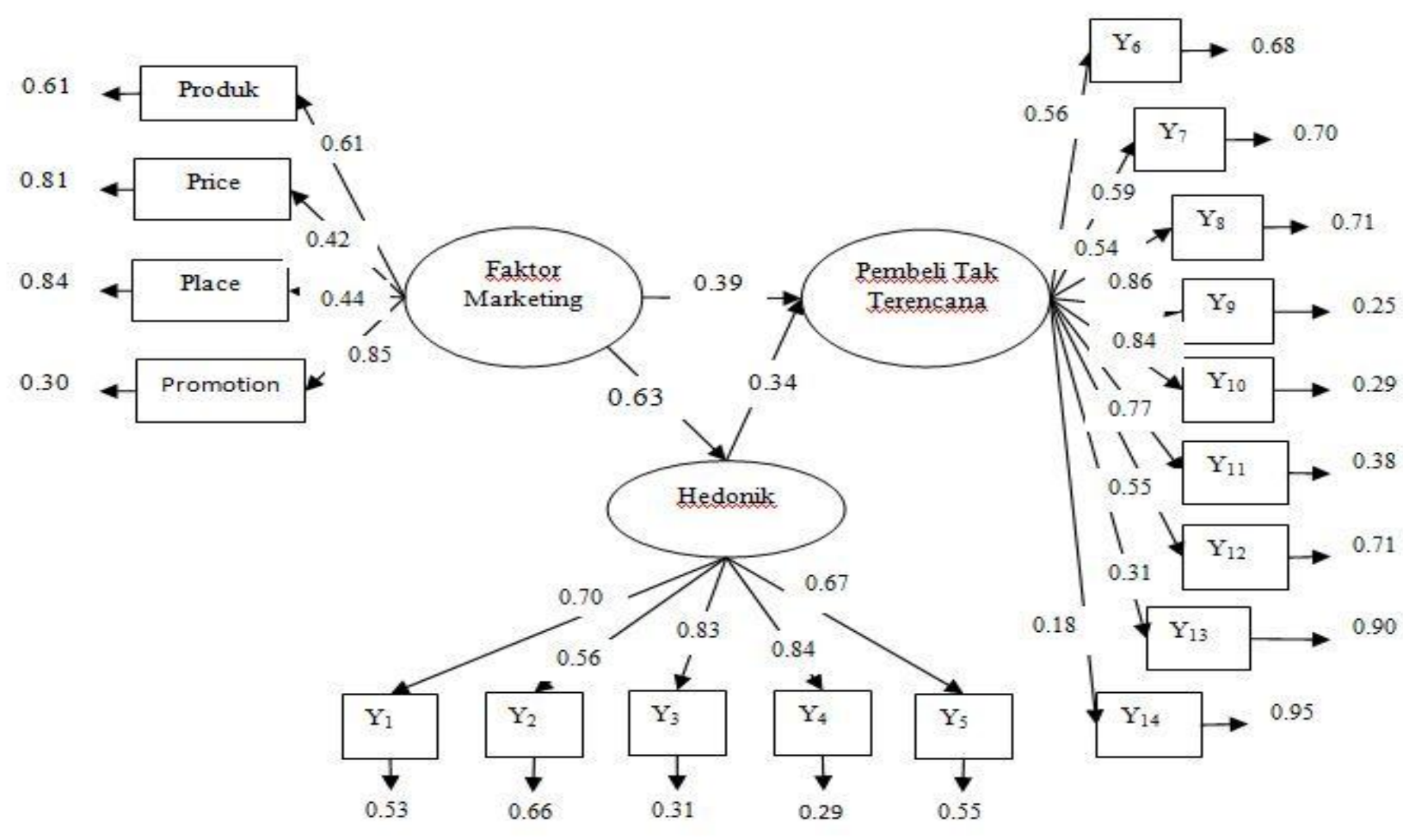

Gambar 1 Diagram hasil estimasi faktor muatan (Ioading factors) 


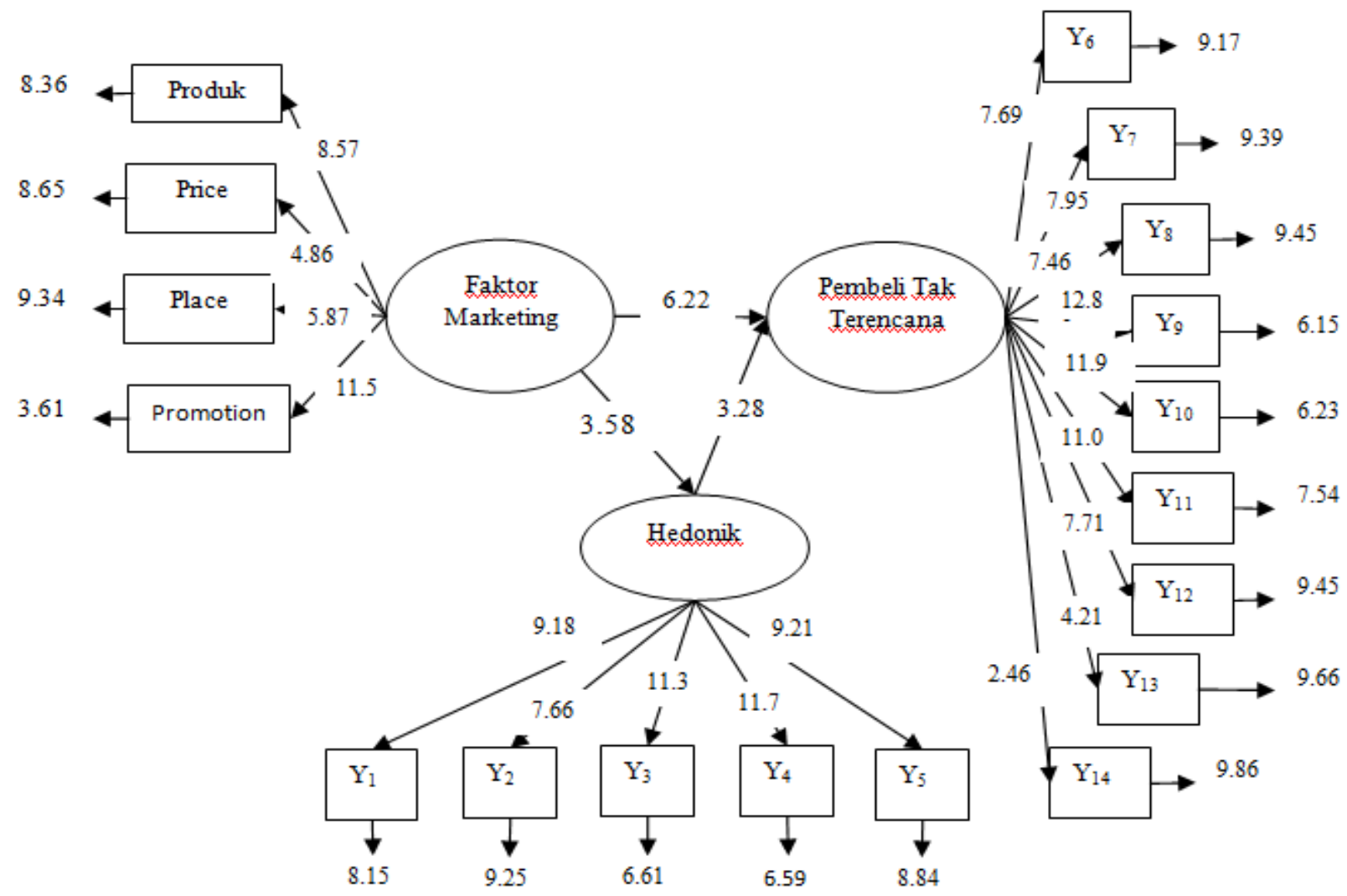

Gambar 2 Diagram uji T

Sementara itu, nilai hedonisme konsumen dalam penelitian ini memiliki lima indikator, yaitu konsumen menikmati kegiatan membeli roti $A B C$, konsumen merasa senang saat membeli roti $A B C$, kegiatan membeli roti $A B C$ merupakan hiburan bagi konsumen, konsumen merasa bersemangat ketika belanja roti $A B C$, dan konsumen merasa bangga saat belanja roti $A B C$. Setelah melakukan pengolahan data pada kelima indikator tersebut terbukti signifkan dan berpengaruh positif. Berdasarkan analisis faktor muatan pada variabel nilai hedonisme konsumen maka indikator konsumen merasa senang saat membeli roti $A B C$ adalah faktor tertinggi yang berpengaruh terhadap nilai hedonisme konsumen sebesar 0,66. Indikator yang paling berpengaruh kedua adalah konsumen merasa bangga saat belanja roti ABC sebesar 0,55, kemudian konsumen menikmati kegiatan membeli roti $A B C$ sebesar 0,53 lalu indikator berikutnya yaitu kegiatan membeli roti $A B C$ merupakan hiburan bagi konsumen sebesar 0,31 , dan yang terakhir indikator konsumen merasa bangga saat belanja roti $A B C$ sebesar 0,29 . Indikator yang mempunyai faktor muatan paling tinggi adalah konsumen merasa senang saat membeli roti $A B C$, kemudian urutan kedua dan ketiga tertinggi adalah konsumen merasa bangga saat belanja roti $A B C$ dan konsumen menikmati kegiatan membeli roti $A B C$. Konsep pemasaran yang dilakukan terbukti mampu membuat hedonisme konsumen meningkat. Konsumen merasa senang, bangga, dan menikmati saat membeli di Gerai Roti ABC. Hedonisme yang tinggi ini pada akhirnya dapat menjadi faktor pemicu dan penambah dalam melakukan pembelian impulsif.

\section{PEMBAHASAN}

Berdasarkan analisis pada karakteristik sosial demografi konsumen pada penelitian ini menunjukkan bahwa berdasarkan jenis kelamin, konsumen wanita lebih mudah melakukan pembelian impulsif. Wanita lebih mudah melakukan pembelian impulsif karena lebih memakai emisional. Sementara itu, pria lebih memakai rasional dalam memutuskan sesuatu. Selain itu, bagi konsumen yang telah memiliki penghasilan sendiri (PNS dan pegawai swasta) akan lebih berperilaku impulsif karena lebih memiliki sumber daya yang diperoleh sendiri untuk membuat keputusan pembelian. Temuan ini sesuai dengan Loudon dan Bitta dalam Widawati (2011) menyatakan bahwa salah satu faktor yang memengaruhi pembelian impulsif adalah kondisi demografi, antara lain 
penghasilan dan pendidikan. Penelitian Harviona (2010) juga menunjukkan bahwa faktor demografi memiliki pengaruh positif terhadap tendensi pembelian impulsif. Temuan penelitian ini semakin memperkuat teori yang menyatakan bahwa faktor demografi, khususnya jenis kelamin, pekerjaan, dan pendapatan memberikan keragaman yang berbeda terhadap pembelian impulsif.

Hasil penelitian ini menemukan bahwa faktor pemasaran berpengaruh signifikan terhadap nilai hedonisme konsumen. Temuan ini menunjukkan bahwa konsumen pada Gerai Roti ABC sangat tertarik dengan strategi penjualan langsung Gerai Roti tersebut yang inovatif dan menarik. Indikator promosi yang diwakili konsep self-service dan open kitchen menjadi faktor utama untuk menarik konsumen datang ke Gerai Roti. Selanjutnya, faktor pemasaran yang berhasil ini akan menyebabkan hedonisme dari konsumen meningkat. Selain promosi, faktor produk juga sangat berpengaruh dalam membuat pelanggan senang dan bahagia yang bisa meningkatkan hedonisme pelanggan. Hasil penelitian ini sesuai dengan hasil penelitian Yistiani (2012) yang mana faktor pemasaran berpengaruh positif terhadap hedonik dan juga terhadap pembelian impulsif.

Selanjutnya, hasil penelitian ini juga membuktikan secara empirik bahwa faktor pemasaran juga berpengaruh signifikan terhadap pembelian impulsif. Hal ini menunjukkan bahwa faktor pemasaran yang meliputi indikator produk, harga, tempat, dan promosi dapat menentukan terjadinya pembelian impulsif. Konsumen roti $A B C$ sangat tertarik dengan konsep promosi penjualan langsung yang inovatif dan menarik. Konsep self-service dan open kitchen yang menjadi andalan untuk menarik konsumen datang ke Gerai Roti ABC membuat konsumen melakukan pembelian impulsif. Selain itu produk yang berkualitas juga mampu membuat konsumen teretarik melakukan pembelian impulsif. Temuan ini sesuai dengan teori Stern dalam Semuel (2006) yang mengidentifikasi hubungan karakteristik produk yang dapat memengaruhi pembelian impulsif, antara lain harga rendah, iklan massa, dan display produk yang menonjol (promosi). Bong (2011) juga melakukan penelitian yang mempunyai kesimpulan terdapat pengaruh signifikan langsung dari upaya in-store stimuli (faktor pemasaran) oleh manajemen toko terhadap perilaku impulsifitas konsumen. Hasil penelitian ini semakin memperkuat teori yang menyatakan bahwa faktor pemasaran, khususnya produk dan promosi, berpengaruh terhadap pembelian impulsif.

Hasil penelitian ini juga menemukan bahwa hedonisme konsumen juga merupakan variabel mediator yang berpengaruh signifikan terhadap pembelian impulsif. Dengan kata lain, rasa bahagia, semangat, dan hiburan dapat memperkuat strategi pemasaran yang dilakukan utnuk memicu munculnya pembelian impulsif. Penelitian Yistiani (2012) juga membuktikan bahwa nilai hedonisme berpengaruh positif dan signifikan terhadap pembelian impulsif. Hasil penelitian ini semakin memperkuat teori yang menyatakan bahwa manfaat/nilai hedonisme berpengaruh terhadap pembelian impulsif.

\section{SIMPULAN DAN SARAN}

Berdasarkan hasil analisis yang telah dilakukan pada konsumen Gerai Roti ABC waralaba yang berlokasi di salah satu pusat perbelanjaan besar di Kota Bekasi dapat disimpulkan bahwa mayoritas konsumen adalah perempuan. Usia mayoritas konsumen berkisar antara 24-29 tahun. Mayoritas konsumen mempunyai pendidikan tinggi yaitu memiliki tingkat pendidikan D3/S1. Konsumen bekerja sebagai pegawai swasta dan mempunyai penghasilan pada rentang $R p$ 2.000.001 hingga Rp 3.000.000. Penelitian ini menemukan bahwa faktor pemasaran secara signifikan meningkatkan hedonisme konsumen dan pembelian impulsif. Selain itu, juga ditemukan bahwa hedonisme konsumen sebagai variabel moderator yang secara signifikan dan positif berpengaruh terhadap terjadinya pembelian impulsif, dari faktor pemasaran.

Formulasi strategi pemasaran yang bisa direkomendasikan kepada manajemen Gerai Roti ABC yaitu mempertahankan faktor pemasaran yang dinilai positif oleh pelanggan, khususnya indikator promosi dan produk. Secara deskriptif indikator promosi yang paling dipersepsikan positif oleh pelanggan adalah sistem open kitchen, konsep self-service, dan aroma roti. Secara deskriptif indikator produk yang paling dipersepsikan positif oleh pelanggan varian roti yang beraneka ragam, rasa roti yang enak dan tampilan roti yang menarik. Dengan mempertahankan serta meningkatkan indikator tersebut, diharapkan pembelian impulsif dan hedonik dapat meningkat.

Pada penelitian selanjutnya, sebaiknya pihak manajemen Gerai Roti ABC juga dilibatkan 
dalam menganalisis pembelian impulsif di Gerai Roti ABC. Saat ini, pesaing di industri makanan semakin banyak sehingga sebaiknya dilakukan penelitian kembali mengenai tingkat pembelian impulsif. Hal ini perlu dilakukan agar perusahaan dapat terus mengukur tingkat pembelian impusif, faktor-faktor penyebabnya, dan tetap bisa bersaing. Selain itu, ada baiknya penelitian lanjutan mempertimbangkan variabel-varabel lain seperti hobi, aspek budaya (suku), layanan, dan atmosfer gerai sebagai variabel bebas yang menentukan pembelian impulsif.

\section{DAFTAR PUSTAKA}

Bong, S. (2011). Pengaruh in-store stimuli terhadap impulse buying behavior konsumen Hypermarket di Jakarta. Ultima Management. 3(1), 31-52.

Fathonah, S. (2009). Pengaruh hedonic shopping motivations dan store attributes terhadap shopper loyalty. Jurnal Siasat Bisnis, 13(3), 287-300.

Harviona, T. V. (2010). Perilaku pembelian impulsif produk pakaian masyarakat urban di Kota Jakarta dan Bandung (tesis). Universitas Indonesia, Jakarta.

Hausman, A. (2010). A multi-method investigation of consumer motivations in impuls buying behavior. Jurnal of Consumer Marketing, 17(5), 403-419.

Hetharie, J. A. (2012). Model kecenderungan pembelian impulsive (studi pada konsumen Matahari Department Store Kota Ambon). Jurnal Manajemen Teknologi, 11(3), 280-294.

Japarianto, E. (2011). Pengaruh shopping life style dan fashion involvement terhadap impulse buying behavior masyarakat high income Surabaya. Jurnal Manajemen Pemasaran, 6(1), 32-41.

Kotler, P. Keller, K. L. (2009). Manajemen pemasaran 1, edisi ke-13. Jakarta, ID: Penerbit Erlangga.

Musriha. (2011). Pengaruh perilaku pembelian hedonic dan ultilitarian terhadap store loyalty di Matahari Departement Store Surabaya. Jurnal Ekonomika, 4(1), 12-18.

Praja, D. D. (2011). Potret gaya hidup hedonisme dikalangan mahasiswa (studi pada mahasiswa FISIP Universitas Lampung). Jurnal sociologie, 1(3).

Rachmawati, V. (2009). Hubungan antara hedonic shopping value, positive emotion, dan perilaku impulse buying pada konsumen ritel. Majalah Ekonomi, 14(2A), 192-209.

Semuel, H. (2006). Respon lingkungan berbelanja sebagai stimulus pembelian tidak terencana pada toko serba ada (toserba) (studi kasus Carrefour Surabaya). Jurnal Manajemen \& Kewirausahaan, 7(2), 152-170.

Solomon, M. R. (2011). Consumer behavior: Buying, having, and being, $9^{\mathrm{TH}}$ edition. New Jersey, US: Pearson.

Susilowati, C. (2012). Pengaruh komunikasi pemasaran terhadap keputusan konsumen dalam menggunakan kartu seluluer im3 melalui motivasi konsumen (studi pada pengguna im3 di Malang). Jurnal Aplikasi Manajemen, 10(1).

Swastha, B. (2006). Azas-azas marketing, edisi ke-3. Yogyakarta, ID: Penerbit Liberty.

Wahdi, N. (2006). Analisis faktor-faktor yang memengaruhi kepuasan pasien sebagai upaya meningkatkan loyalitas pasien (studi empiris pada Rumah Sakit Panti Wilasa "Citarum" Semarang) (tesis). Program Studi Magister Manajemen Universitas Diponegoro, Semarang.

Widawati, L. (2011). Analisis perilaku "impulse buying" dan "locus of control" pada konsumen di carrefour Bandung. Jurnal Mimbar, 27(2).

Wuryanto, B. A. (2007). analisis faktor-faktor yang memengaruhi kinerja word-of-mouth marketing (wom) studi pada hungry buzz diner Semarang (tesis). Program Studi Magister Manajemen Universitas Diponegoro, Semarang.

Yistiani, N. N. M. (2012). Pengaruh atmosfer gerai dan pelayanan ritel terhadap nilai hedonisme dan pembelian impulsif pelanggan Matahari Department Store Duta Plaza di Denpasar (tesis). Program Pascasarjana Universitas Udayana, Denpasar. 